\title{
Plasma retinol concentration in grazing heifers: First data obtained from a dairy herd in the south of Chile ${ }^{\#}$
}

\author{
Concentraciones plasmáticas de retinol en vaquillas a pastoreo: \\ Primeros valores obtenidos en un rebaño del sur de Chile \\ RH Chihuailaf*, CS González, F Wittwer, PA Contreras \\ Instituto de Ciencias Clínicas Veterinarias, Facultad de Ciencias Veterinarias, Universidad Austral de Chile.
}

\begin{abstract}
RESUMEN
En Chile no existen antecedentes sobre la concentración de retinol en plasma sanguíneo de bovinos a pastoreo, por ello el objetivo de este estudio fue medir las concentraciones plasmáticas de retinol en vaquillas a pastoreo en invierno y primavera y comparar ambos períodos. Para el estudio se utilizaron 15 vaquillas Frisón negro, clínicamente sanas, entre 16 y 18 meses de edad, mantenidas a pastoreo sobre praderas naturales mejoradas. Mensualmente de cada animal se obtuvo muestras de sangre, desde julio hasta diciembre. Las concentraciones plasmáticas de retinol se midieron utilizando cromatografía líquida de alto rendimiento en fase reversa. Los valores promedios de las concentraciones plasmáticas de retinol fueron de $0,46 \pm 0,09 \mu \mathrm{g} / \mathrm{ml}(\mathrm{rango}$ de 0,18 a $0,69 \mu \mathrm{g} / \mathrm{ml}$ ). En invierno se observan los valores más bajos $0,42 \pm 0,09 \mu \mathrm{g} / \mathrm{ml}$ (rango 0,18 a $0,57 \mu \mathrm{g} / \mathrm{ml}$ ) y en primavera los más altos $0,50 \pm 0,09$ $\mu \mathrm{g} / \mathrm{ml}$ (rango 0,29 a $0,69 \mu \mathrm{g} / \mathrm{ml}$ ). Los valores promedio de concentraciones plasmáticas de retinol, obtenidos en este estudio, son los primeros datos presentes en Chile en bovinos mantenidos a pastoreo.
\end{abstract}

Palabras clave: vaquillas, retinol, invierno, primavera.

Key words: heifers, retinol, winter, spring.

\section{INTRODUCTION}

Vitamins are organic molecules with a complex structure, which are essential in very small quantities for the health, growth and reproduction of ruminants. The generic term vitamin $\mathrm{A}$ is used when referring to retinoids that exhibit the biological activity of retinol (IUNS 1990) and includes both natural forms and synthetic analogues. Vitamin A is physically a pale yellow crystalline solid substance, which is water insoluble. Chemically, it is a hydrophobic $\beta$-ionone ring with a conjugated isoprenoid lateral chain containing a polar group at its end (Debier and Larondelle 2005). The ability to synthesize compounds with vitamin A activity is limited to microorganisms and plants (Harrison 2005). Thus, animals must obtain vitamin A from the diet, where it can be found as a preformed vitamin in animal foods or as a provitamin in plant foods. Provitamins are members of the carotenoid family, and the term is used as a generic description of all the compounds that exhibit qualitatively the biological activity of $\beta$-carotene (IUNS 1990). $\beta$-carotene is one of the most widely available carotenoids and the main precursor of vitamin A (During and Harrison 2004).

It is known that in animals, vitamin A intervenes in a variety of biological mechanisms associated to the maintenance of epithelial cells, gene regulation, immune cell

Accepted: 07.03.2007.

\# Fellowship Mecesup. P.O.B. 567, Vadivia, Chile; rchihuailaf@uach.cl function, reproduction and vision (Chew 1987, Debier and Larondelle 2005). Due to the above mentioned, the most frequent signs of deficiency are: impaired dark adaptation, xerophthalmia with the cornea becoming thick and hazy, decreased cellular and humoral immunity. In male animals it can cause degenerative damage of epithelial cells in seminiferous tubules while in the female it leads to abortion, delivering stillborn or weak foetuses and placental retention (Radostits et al 2002).

According to Herdt and Stowe (1991) the evaluation of vitamin A metabolic balance is not a routine practice in animals but it should be considered as part of the general health diagnosis of the herd, especially if there is evidence of a decrease in reproductive efficiency and immunosuppression of unknown origin. Hammell et al (2000) have mentioned that the hepatic concentration of vitamin A is the most reliable indicator used to evaluate the metabolic balance of vitamin A in animals. However, even though the determination of plasma concentration of retinol is a less sensitive indicator, it is the most practical and useful method to evaluate the status of vitamin A in the herd (Herdt and Stowe 1991), with plasma concentrations between 25 and $60 \mu \mathrm{g} / \mathrm{dL}$ indicating an acceptable level of the vitamin in adult cattle (Frye et al 1991).

Plasma concentration of vitamin A is usually expressed as the addition of retinol and retinyl palmitate concentrations; however, retinol gives more clinical information and can be measured through chromatographic techniques (Herdt and Stowe 1991). High Performance Liquid Chromatography 
(HPLC) is used to separate molecules with a high analytical sensitivity (Paulo et al 1999), making it a useful tool to determine vitamin concentration in bovines.

Retinol requirements have been the subject of many studies. According to ARC (1980) the daily requirements of retinol are $20 \mu \mathrm{g} / \mathrm{kg}$ of body weight for maintenance and growth, $30 \mu \mathrm{g} / \mathrm{kg}$ of body weight during breeding and pregnancy and 25 to $65 \mu \mathrm{g} / \mathrm{kg}$ of body weight for lactating cows. NRC (2001) mentions that vitamin A, expressed as retinol equivalents, should be supplemented in amounts of $24 \mu \mathrm{g} / \mathrm{kg}$ of body weight during growth and $33 \mu \mathrm{g} / \mathrm{kg}$ of body weight during lactation, pointing out that these values do not represent the total requirement of the vitamin and consider animals being fed conserved forage.

In the south of Chile, the management system for dairy cows is based on grazing pasture and the supplementation with concentrate and conserved forage is used in critical periods (Pulido et al 1999). Considering that green fresh forage is the main source of vitamin A precursors, it is possible to estimate that the contribution should be adequate for grazing cattle; however, the quality and quantity of the forage provided by the pasture changes throughout the year, under which circumstances the nutrient contribution could vary. Furthermore, most grains are void of carotenoids and the stored forages have lower concentrations of them (NRC 2001). In Chile there are no records about vitamin A status in dairy neither beef cattle; it could limit the nutritional management and the efficiency of the herd.

The aim of this study was to measure the plasma retinol concentration in grazing heifers using a standardized analytic methodology and to record its variation during winter and spring in a herd in southern Chile.

\section{MATERIAL AND METHODS}

Experimental animals. Fifteen Black and White Friesian heifers were selected from a dairy herd. The animals were clinically healthy, weighed $253 \pm 40 \mathrm{~kg}$, and belonged to a farm located in the Valdivia province (39 S, $73 \mathrm{O}$ ), Chile. Each animal had two tags, a metal one provided by the farm and a plastic one assigned for the purposes of this study.

Management and feeding. During the winter and spring periods the heifers were maintained grazing improved pasture composed mainly of cocksfoot (Dactylis glomerata), yorkshire fog (Holcus lanatus), ryegrass (Lolium spp.) and white clover (Trifolium repens). During the winter, they were supplemented with silage originated from the same type of pasture.

Collection and handling of samples. Blood samples were obtained monthly during the winter (July to September), and also during the spring (October to December), making a total of six samples per animal. A blood sample $(8 \mathrm{ml})$ from each heifer was collected in heparin tubes through jugular venopunction and then centrifuged at $1500 \mathrm{~g}$ for 10 minutes to obtain plasma which was kept in plastic tubes, frozen and stored at $-25^{\circ} \mathrm{C}$ until the day of assay.

Sample preparation for chromatographic analysis. The plasma retinol concentration was determined through reverse-phase HPLC according to a technique proposed by Paulo et al (1999), with modifications. Briefly, the sample underwent extraction under indirect light. A $1 \mathrm{ml}$ of plasma was transferred into a glass tube and $100 \mu \mathrm{l}$ of retinyl acetate was added $(15 \mu \mathrm{g} / \mathrm{ml})$ as internal control, then $2 \mathrm{ml}$ of ethanol and $3 \mathrm{ml}$ of cyclohexane, which contained $0.01 \%$ of tert-butylated hydroxytoluene, were added. The sample was vortex-mixed for 10, 20 and 45 seconds after each addition, respectively. Immediately after, the sample was centrifuged at $2000 \mathrm{~g}$ for 10 minutes at $4{ }^{\circ} \mathrm{C}$. The cyclohexane top layer was recovered and placed into a glass tube to be evaporated in a water bath at $37^{\circ} \mathrm{C}$ under nitrogen stream. The dry sample was reconstituted in $100 \mu \mathrm{l}$ of an ether-ethanol solution $(1: 9 \mathrm{v} / \mathrm{v})$ under constant agitation to remove the material adhered to the tube walls. The sample was then ready to be injected into the HPLC column.

Instrumentation, chromatographic conditions and quantification. A PE Nelson HPLC Chromatograph $®$ (Perkin-Elmer Co.) equipped with a UV-Vis detector and a Kromasil@ (Akzo Nobel, Swedeen) $\mathrm{C}_{18}$ column (150 x $4.6 \mathrm{~mm}$ y $4.5 \mu \mathrm{m}$ ) was used. In the chromatographic analysis, the mobile phase used was methanol delivered at a flow-rate of $1.5 \mathrm{ml} /$ minute. All the solvents used were HPLC grade. The retinol standards were prepared in ethanol, protected from light. Identification of retinol and retinyl acetate was carried out comparing their retention time, with standards at $325 \mathrm{~nm}$, respectively. The retinol concentration was calculated from a standard curve made with the peak area of each retinol standard, adjusting it previously to the recovery of the internal control ( mean $=92.5 \%)$. The retinol concentration was expressed in $\mu \mathrm{g} / \mathrm{ml}$ of plasma. The precision of the method was determined by replicate analysis $(\mathrm{n}=10)$ and the coefficient of variation was $1.44 \%$. The linearity was checked using five standard solutions with concentrations ranging from $1 \mu \mathrm{g} / \mathrm{ml}$ to $15 \mu \mathrm{g} / \mathrm{ml}$. The correlation coefficient of the calibration curves was $>0.998$.

Statistical analysis. The data obtained were expressed as means $(\bar{x})$ and standard deviation (SD) for each sampling period. Homocedasticity and distribution of data through a Bartlett and Shapiro-Wilks test was evaluated. Repeated measures ANOVA test followed by Tukey's multiple comparison test when necessary, was performed. A value of $\mathrm{P}<0.05$ was considered significant. 


\section{RESULTS AND DISCUSSION}

Mean plasma retinol concentration obtained from the 15 animals was $0.46 \pm 0.09 \mu \mathrm{g} / \mathrm{ml}$ with values fluctuating between 0.18 and $0.69 \mu \mathrm{g} / \mathrm{ml}$. Mean plasma retinol concentration obtained from the winter period was $0.42 \pm 0.09 \mu \mathrm{g} / \mathrm{ml}$ while the mean from the spring sampling periods was $0.50 \pm 0.09 \mu \mathrm{g} / \mathrm{ml}$ (table 1 ). The lowest retinol concentration $(0.41 \pm 0.08 \mu \mathrm{g} / \mathrm{ml})$ was observed at the beginning of winter (July) and after that, it started to increase until October $(0.53 \pm 0.10 \mu \mathrm{g} / \mathrm{ml})$ maintaining that level until the end of the study period (figure 1). Levels of plasma retinol were similar during winter. In addition, no differences were detected among the spring samples, but when comparing both sampling periods it was found that plasma retinol concentration was higher in spring $(\mathrm{P}<0.01)$.

Since the animals of this study were all grazing improved pastures, the differences exhibited between the sampling

Table 1. Plasma retinol concentrations $(\bar{x} \pm \mathrm{SD})$ from 15 grazing heifers during winter and spring months.

Concentraciones plasmáticas de retinol $(\bar{x} \pm \mathrm{DE})$ en 15 vaquillas a pastoreo en períodos de invierno y primavera.

\begin{tabular}{lcc}
\hline \multirow{2}{*}{ Period } & \multicolumn{2}{c}{ Retinol plasma concentration $(\mu \mathrm{g} / \mathrm{ml})$} \\
\cline { 2 - 3 } & $\bar{x} \pm \mathrm{SD}$ & Range \\
\hline Winter* $^{*}$ & $0.42 \pm 0.09^{\mathrm{a}}$ & $0.18-0.57$ \\
Spring** & $0.50 \pm 0.09^{\mathrm{b}}$ & $0.29-0.69$ \\
$\bar{x}$ Total & $0.46 \pm 0.09$ & $0.18-0.69$ \\
\hline
\end{tabular}

Different letters show $\mathrm{P}<0.05$.

* Samples obtained on July, August and September.

** Samples obtained on October, November and December.

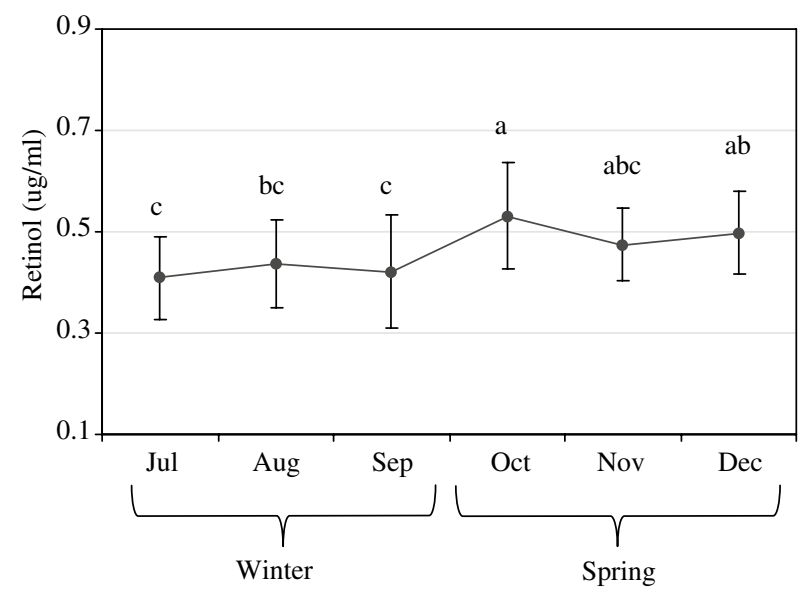

Figure 1. Variations of plasma retinol concentrations $(\bar{x} \pm \mathrm{SD})$ in 15 grazing heifers at winter and spring months. Different letters show $\mathrm{P}<0.05$.

Variaciones de las concentraciones plasmáticas de retinol $(\bar{x} \pm \mathrm{DE})$ en 15 vaquillas a pastoreo en los meses de invierno y primavera. Letras diferentes indican $\mathrm{P}<0,05$. periods are an expression of the pasture contribution. In the south of Chile the forage supplied by pastures varies in quality and quantity throughout the year, affecting nutrient supply. Plasma retinol concentration increase during spring suggests an improvement in the supply of $\beta$-carotene provided by the forage. Plasma concentration of $\beta$-carotene was not determined in this study, being impossible to estimate it from plasma retinol concentration because the conversion rate of $\beta$-carotene to retinol in the intestinal epithelium decreases with a high $\beta$-carotene diet (Çetínkaya and Özcan 1991).

Retinol circulates in blood, mainly linked to specific binding proteins, and its concentration is under a homeostatic control from the liver (Debier and Larondelle 2005). This organ acts as a compartment for retinol stores in the form of retinyl palmitate, controlling its release into general circulation while maintaining concentration within a narrow interval. The capacity to maintain retinol concentration is lost when the hepatic store of the vitamin is near to depletion (Tanumihardjo 2004). It has been estimated that hepatic stores under $20 \mu \mathrm{g}$ of vitamin/g of fresh tissue lead to a drastic fall in the retinol plasma concentration, signalling a severe deficiency of vitamin A (Herdt and Stowe 1991). In this study, the mean retinol concentration suggests that hepatic store in heifers was good enough to avoid strong fluctuations in the plasma retinol concentrations between periods.

Although it was not possible to find vitamin values for grazing heifers in the consulted literature, research conducted in Turkey to evaluate vitamin A serum status by HPLC of Holstein and Brown Swiss cross cows fed with concentrates and silage during winter, and kept grazing on pastures and supplemented with concentrate during spring, determined that retinol concentration increased during spring. According to the authors, the increase of the serum levels of retinol is due to a higher concentration of $\beta$-carotene in the green forage towards spring months (Çetínkaya and Özcan 1991).

A similar study in which serum concentration of vitamin A was determined using spectrophotometry method in Holstein cows fed with hay and silage in winter and kept grazing during the summer, showed mean values of $0.31 \pm 0.09$ to $0.40 \pm 0.08 \mu \mathrm{g} / \mathrm{ml}$ (Tekpetey et al 1987). These concentrations are lower than the ones obtained in this study.

Another study indicated that vitamin A levels, determined through HPLC in blood serum from 13 cows ranging 2 to 17 years old, kept under confinement and fed green forage, hay and commercial concentrates, was $0.21 \pm 0.01$ $\mu \mathrm{g} / \mathrm{ml}$, with values fluctuating between 0.10 to $0.45 \mu \mathrm{g} / \mathrm{ml}$ (Katamoto et al 2003). In this case the grazing conditions (permanent grazing) were different from those applied to the heifers in the present study.

Therefore, heterogeneity of experimental designs and the groups of animals used in the studies pointed out above does not allow the comparison of those values with the 
ones obtained in this study. Although this study indicates the first retinol values in grazing heifers in the south of Chile and propose a measurement procedure, further investigations are needed in order to determine the vitamin A metabolic balance in different physiological conditions and production levels of the animals, and also to determine the level needed to satisfy the requirements in the management system used in the south of Chile.

\section{SUMMARY}

There is no information available about plasma retinol concentration in grazing heifers in Chile, for this reason the plasma retinol concentration was measured in dairy heifers grazing during the winter and spring seasons on paddocks in the south of Chile. Fifteen clinically healthy Friesian heifers from a dairy farm located in the Valdivia Province, Chile, aged between 16 and 18 months, were used. The animals were grazing on fertilized natural pastures from July to December. Blood samples were taken monthly from each animal and plasma retinol concentrations were determined using reverse-phase high performance liquid chromatography. Mean $( \pm \mathrm{SD})$ plasma retinol concentration was $0.46 \pm 0.09 \mu \mathrm{g} / \mathrm{ml}$ with values fluctuating between $0.18-0.69 \mu \mathrm{g} / \mathrm{ml}$. Plasma retinol concentration was lower in winter $(0.42 \pm 0.09 \mu \mathrm{g} / \mathrm{ml}$, with values fluctuating between 0.18 to $0.57 \mu \mathrm{g} / \mathrm{ml})$ and higher in spring $(0.50 \pm 0.09 \mu \mathrm{g} / \mathrm{ml}$; with values fluctuating between 0.29 to $0.69 \mu \mathrm{g} / \mathrm{ml}$ ). The average values obtained in this study constitute the first data currently available in Chile regarding plasma retinol concentration in grazing cattle.

\section{ACKNOWLEDGEMENTS}

This study was supported by Proyecto Mecesup AUS005 and Programa Doctorado en Ciencias Veterinarias, Universidad Austral de Chile.

\section{REFERENCES}

ARC, Agricultural Research Council. 1980. The nutrient requirements of ruminant livestock. Commonwealth Agricultural Bureaux, London, England.
Çetínkaya N, H Özcan. 1991. Investigation of seasonal variations in cow serum retinol and $\beta$-carotene by high performance liquid chromatographic method. Comp Biochem Physiol 100A, 1003-1008.

Chew BP. 1987. Vitamin A and $\beta$-carotene in host defense. J Dairy Sci 76, 2795-2803.

Debier C, Y Larondelle. 2005. Vitamins A and E: metabolism, roles and transfer to offspring. Br J Nutr 93, 153-174.

During A, EH Harrison. 2004. Intestinal absorption and metabolism of carotenoids: insights from cell culture. Arch Biochem Biophys 430, 77-88.

Frye TM, SN Williams, TW Graham. 1991. Vitamins deficiencies in cattle. Vet Clin North Am: Food Anim Pract 7, 217-275.

Hammell DC, ST Franklin, BL Nonnecke. 2000. Use of the relative dose response (RDR) assay to determine vitamin A status of calves at birth and four weeks of age. J Dairy Sci 83,1256-1263.

Harrison EH. 2005. Mechanism of digestion and absorption of dietary vitamin A. Annu Rev Nutr 25, 87-103.

Herdt TH, HD Stowe. 1991. Fat-soluble vitamin nutrition for dairy cattle. Vet Clin North Am: Food Anim Pract 7, 391-415.

IUNS, International Union of Nutritional Science. 1990. Nomenclature Policy: Generic descriptors and trivial names for vitamins and related compounds. J Nutr 120, 12-19.

Katamoto H, Y Yamada, S Nishizaki, T Hashimoto. 2003. Seasonal changes in serum vitamin $A$, vitamin $E$ and $\beta$-carotene concentrations in Japanese Black Breeding cattle in Hyogo prefecture. $J$ Vet Med Sci 62, 1001-1002.

NRC, National Research Council. 2001. Vitamins. In: National Research Council (ed). Nutrient Requirements of Dairy Cattle. National Academic Press, Washington DC, USA, Pp 162-164.

Pulido R, M Cerda, W Stehr. 1999. Efecto del nivel y tipo de concentrado sobre el comportamiento productivo de vacas lecheras en pastoreo primaveral. Arch Med Vet 31, 177-187.

Radostits OM, CC Gay, DC Blood, KW Hinchcliff. 2002. Enfermedades causadas por deficiencia de vitaminas liposolubles. En: Radostits OM, Gay CC, Blood DC, Hinchcliff KW (eds). Medicina Veterinaria. McGraw-Hill Interamericana, Madrid, España, Pp 1841-1849.

Tanumihardjo SA. 2004. Assessing vitamin A status: past, present and future. J Nutr 134, 290S-293S.

Tekpetey FR, WM Palmer, JR Ingalls. 1987. Seasonal variation in serum $\beta$-carotene and vitamin $\mathrm{A}$ and their association with postpartum reproductive performance of Holstein cows. Can J Anim Sci 67, 491-500. 